\title{
Diet and milk secretion in women
}

\author{
By Mavis Gunther, Child Welfare Department, University College Hospital, \\ London, $W C_{\mathrm{I}}$
}

It is difficult in a symposium such as this to deal with human lactation because so much more is known about lactation in other mammals. Their physiology has been dealt with in the preceding papers and, since mothers offer only very limited experimental opportunities for study, one is left groping, relying for much of the understanding of the subject on animal investigations and yet aware all the time that species differences may make translation of findings from, say, bovine to human galactology unjustified and even misleading.

\section{Diet and amount of secretion}

In man it appears from isolated instances that sustained underfeeding in childhood may be severe enough to impair the development of secondary sexual characteristics and result in inadequate mammary tissue, but there has been no proper study. Nor have there been publications specifically dealing with the relationship of overall intake in pregnancy or labour to subsequent lactational performance. In women the course of a lactation is set by the end of the Ist week and too little consideration has been given up till now to the nutrition of the mother during labour and immediately afterwards.

Where a mother is able to satisfy her appetite there is little reason to think that persuading her to eat more calories will affect the volume of milk secreted, but paradoxically the addition to her diet of some items can reduce secretion. Foremost of these is water. Illingworth \& Kilpatrick (1953) have shown that the drinking of water in amounts beyond the natural inclination of thirst impairs lactation. It is believed that the waterlogging suppresses the liberation of posterior pituitary sccretion. In a few instances of very ample secretion where the women's urine has been tested it has been highly concentrated and the normal condition of a lactating woman would appear to be one of limited urinary secretion. Dehydration only produces reduction in milk secretion when the fluid intake over $12 \mathrm{~h}$ or so is about equal to or less than the volume of milk being secreted. It is possible for a woman to go into anuria before lactation is reduced.

Many attempts have been made to assess the effects of famine or near famine on human lactation. The difficulty has been to find a good observable measure. Probably the first description was by Descaine ( $187 \mathrm{I}$ ) during the siege of Paris. He reported that of forty-three women attempting to feed their children sixteen had insufficient milk and twelve babies died of hunger. Twelve others were thought to have had enough milk but at the expense of the mother. There have been many accounts since then mostly relating to the I 9 I $4-\mathrm{I} 8$ war, and during the $1939-45$ war investigations were reported from Paris (Lavagne \& Mathieu, I943), the siege of Leningrad (Antonov, 1947), Finland (Salmi, 1944), Poland (von Sydow, 1945) and Holland 
(Smith, 1947). Throughout, the authors have mostly been concerned about the fat content but, with so little opportunity to regulate the methods of sampling, the results are inconclusive. It was thought that in the brief but very acute Dutch famine (1944-5) the proportion of mothers feeding their babies from the breast was the same as it had been before (Jonxis, quoted by Smith, I947). The records kept at the Landesfrauen-klinik, Wuppertal enabled Dean (195I) to show that average daily secretion of milk on the 7 th day post-partum was about 2 oz less in 1945 and 1946 than it had been in 1938 . One concludes that with the wide variety among human beings some women are able to feed their babies despite appalling adversity but that severe undernutrition reduces the proportion.

\section{Nitrogenous substances}

The total nitrogen content is high in colostrum, falls rapidly in the Ist week and declines continuously and slowly during lactation until, in the very last days, the secretion (regression milk) becomes likc colostrum and the nitrogen level rises again. The figures given for women in America (Bell, 1928), in wartime Britain (Kon \& Mawson, 1950) and postwar Germany (Gunther \& Stanier, 195I) are very similar and the recent estimates by Belavady \& Gopalan (1959) for poor Indian women show no obvious differences. Those for New Hebridean women (Peters, 1953) are rather above the concensus. On the other hand the figures given by Deb \& Cama (1962) from Bangalore and by Jansen, Luyken, Malcolm \& Willems (1960) for Papuan women are lower, the latter finding protein values of 0.88 even early in lactation. Jansen describes the women as having an average height of $149.7 \mathrm{~cm}$ and weight of $40 \cdot \mathrm{I} \mathrm{kg}$; haemoglobin $8 \cdot 2 \mathrm{~g} / 100 \mathrm{ml}$. It is impossible on this evidence to know whether the amount of protein in the milk is attributable to climatic or racial differences or the diet which consisted mostly of tubers with occasional animal protein 'of pigs, crabs, lizards, larvae and forest animals'.

Belavady, Venkatachalam \& Gopalan (1961) in Hyderabad and Deb \& Cama ( 1962 ) in Bangalore studied the effects of giving supplements of $30 \mathrm{~g}$ dried skim milk and $50 \mathrm{~g}$ casein respectively to women on basal diets containing $45-55 \mathrm{~g}$ protein. The protein content of the milk was not significantly altered but, curiously, the creatine content went down during supplementation. Deb \& Cama (1962) found that the supplements produced an increase of whey protein in relation to curd in the milk and the increase correlated with Fraction I, thought to be a milk serum albumin fraction. The serum albumin increased a little with supplementation. Karmarkar \& Ramakrishnan ( 1960 ) made a survey of the diets and milk composition of women in Baroda. By classing their subjects in quartiles according to the amounts of different components of the diets, it was shown that women receiving less than $34.3 \mathrm{~g}$ protein a day had on average a lower protein content in their milk than the mothers in each of the better-fed groups. They concluded that above a certain very low intake further increase did not alter the milk's composition. The interaction of diet, genetic make-up and milk secretion was shown by Fisch, Jenness, Doeden and Anderson (1967), who compared the serum and milk levels of phenylalanine after 
feeding different doses of it to two women who were phenylketonuria heterozygotes and to two normal women. 'The serum levels rose, of course, much more in the heterozygotes than in the controls; the content in milk rose in that from both pairs of women but was much higher in that from the heterozygotes. Even so, the increase in serum was several times that in milk and it is presumed that there is some barrier to the transfer to the milk of a proportionate increase.

There is another quite different consideration about the protein content of human milk. Using the Prausnitz-Küstner technique Donnally (I929) showed beyond argument that traces of egg protein are secreted in milk by mothers who have eaten raw eggs. There is no reason to think that this finding applies only to egg proteins.

\section{Fat}

For long the complexities of sampling for the determination of milk fat, first commented on by Thomas Young ( $176 \mathrm{r}$ ), bedevilled most investigations. In women the gradient in fat content between fore and hind milk is steep and the milk ejection reflex variable, and in the normal course emptying to any kind of consistent endpoint is not to be expected of the baby at all feeds in the day. Residual milk can contribute markedly to the composition of the next sample withdrawn. In addition, where precautions have been taken against all these items a big diurnal variation is found. Investigations into total fat content are therefore only of significance where they have been based on $24 \mathrm{~h}$ sampling from one breast or, in lesser intervals, have kept to appropriate safeguards. The early literature has been summarized by Gunther \& Stanier (195I). Estimates by Deem (1931), Ruzicic (1936), Gunther \& Stanier (I95I) and recent similar investigations involving experimental variation of diet (Insull, Hirsch, James \& Ahrens, I959, Pokorný, Kohn \& Pliska, I963) suggest that the variation in fat content is small until very large additions of fat have been made, in some instances of up to $25^{\circ} \mathrm{g}$ fat a day. It seems fair to assume that these women were ketotic. Ruzicic (1936) also found an increase in fat content during a period of starvation. It appears that over a fairly wide range of variability in intake, the mother's metabolism provides for her homoeostasis and this, reflected in the composition of her milk, provides for the child's as well. Some accounts show a reduction in volume of milk secreted while fat constituted a very large part of the diet. There remains the curious finding that, despite the relative constancy from day to day of fat secretion, human milk shows a marked diurnal variation in fat content and this is not influenced by levelling out the calorie and fat intake by the mother during the $24 \mathbf{h}$ (Gunther \& Stanier, I949). 'The influence of the diet on the fatty acid distribution is, on the other hand, very great and has been the subject of several investigations (Soderhjelm, r953; Insull \& Ahrens, r959; Insull et al. 1959; Pokorný et al. 1963; Krámer, Szöke, Lindner \& Tarján, 1965; Read \& Sarrif, 1965; Read, Lutz \& Tashjian, 1965). The esterified fatty acids lauric (C12:0) and myrisitic (Cr 4:0) are scanty in the colostrum in pregnancy and immediately after delivery, but lauric acid increases on the 2 nd day and both on the 3 rd. These two also increase when the mother is on a fat-free high-carbohydrate diet; they are presumed to be synthesized 
in the body and, since they rise with the inception of lactation, it is believed that they are synthesized by the mammary gland. Their relative and absolute amounts are reduced when $70 \%$ of the dietary calories come from fat. Palmitic acid is the most constant in proportion among the components and is probably derived from food fats; palmitoleic acid may be partly synthesized by the gland. It appears that all the longer acids and all the polyunsaturated acids come from ingested fat. Fat eaten affects the composition of the milk fat about $8 \mathrm{~h}$ later but when there is a big change in the diet the composition of the milk fat may continue to shift for several days to that more like the fat eaten. Insull \& Ahrens (1959) have pointed out that 'it seems necessary to postulate that the dietary fatty acids are first transported to some intermediate pool of considerable size and later into the milk'.

\section{Minerals}

Colostrum and milk are isotonic with the mother's blood. The potassium content rises slightly and the sodium falls much more in the secretion over the first days as the amount of lactose rises (Tanasiǐchuk, 1965). Nevertheless, radioactive studies have shown that sodium ingested is represented in the milk within $20 \mathrm{~min}$ (Pommerenke \& Hahn, 1943). This may be viewed as part of the freedom within the whole body's pool. There is however a small diurnal variation in both potassium and sodium which is out of phase with adrenal secretion, and by day the sodium content is greater in fore milk than in hind milk; perhaps this occurs through the permeability of the ducts under the influence of the diet (Gunther, Hawkins \& Whyley, 1965). Calcium, which varies the most of all constituents of milk from woman to woman appears to be unaffected by diet but to be almost constant for one individual. Lactation may bring a negative balance, but constant accretion may not necessarily always be an advantage. Strontium-9o is only present in the milk if taken by the mother.

Radioactive iodine reaches the milk within 5 min of ingestion. Although investigations with ${ }^{131}$ I have dealt in trace amounts, there is little doubt that iodides like bromides if taken pass into the milk. Iodine given to the mother however reduces her secretion of thyroid-stimulating hormone and consequently the secretion of milk. This treatment has its occasional use when lactation is unaffected by oestrogens in reducing excess lactation but is only justified if the giving of iodine is not about to be needed in the medical care of hyperthyroidism. The use of iodized casein in problems of human lactation is unjustified.

\section{Vitamins}

The normal range of vitamin content in human milk, the effects of supplements, the variations with duration of lactation and the time scale of effects of supplements were described in the classic work of Kon \& Mawson (1950). The vitamins will be considered here more according to their time scale than alphabetical order. It is the breast-fed baby who is most likely to suffer vitamin $\mathrm{K}$ deficiency. Dyggve, Dam \& Sondergaard (1956) have shown that neither form of vitamin K given to the mother 
after delivery alters the prothrombin time in breast-fed babies until too late (about 4 days) to protect the baby at risk. One suspects that absence of green vegetables in the diet just before delivery and enemata depriving the mother of her colonic source of vitamin $\mathrm{K}$ cause the baby to be deficient at birth. The shared deficiency in mother and baby, reflected in the early milk, is disastrous to the baby.

The riboflavine content of milk is immediately responsive to supplements, and Deodhar, Rajalakshmi \& Ramakrishnan (1964) have found that with persistent supplementation far higher amounts in milk were recorded than in earlier surveys. Thiamine deficiency may yet be contributing to convulsions (Rao \& Subrahmanyan, r964) and sudden death (Cruickshank, Trimble \& Brown, 1957). Fehily (1944) has pointed out that the baby whose mother has beriberi is at a double disadvantage since methyl glyoxal passes into the milk.

Cyanocobalamin, studied by $\left.{ }^{58} \mathrm{Co}\right]$ vitamin $\mathrm{B}_{12}$, was found by Luhby, Cooperman, Donnefeld, Herrero, Teller \& Wenig ( $\left.195^{8}\right)$ to reach milk in increasing amounts from $24 \mathrm{~h}$ to 6 days after ingestion although the blood level reached its peak in $18-30$ $\mathrm{h}$. The amount secreted in milk was very small but dosing the baby direct resulted in up to $95 \%$ absorption. Matoth, Pinkas \& Sroka (1965) have described the high folate levels in the serum of breast-fed infants which are higher than that of their mothers. They estimate that the baby's need is of the order of $20 \mu \mathrm{g}$ a day. The passage of $p$-aminobenzoate to the infants via the milk in primates has been described by Hawking (1954); his findings presumably apply to man.

Vitamin A was shown by Kon \& Mawson (1950) to decrease with the duration of lactation during the first 20 weeks. A single dose, given as liver (Tarján, Kramer, Szöke \& Lindner, 1963 ) doubled, the amount in milk in about $12 \mathrm{~h}$. The concentration fell to the previous value in $48 \mathrm{~h}$.

Ascorbic acid also reflects the amount eaten but appears to have a maximum value between 6 and $7 \mathrm{mg} / 100 \mathrm{ml}$ (Kon \& Mawson, 1950; Deodhar, et al. 1964), but when the mother's intake falls the amount secreted in the milk may exceed her intake. Deodhar and his colleagues calculated that women of low nutritional status in Baroda were secreting $\mathrm{I}_{4} \mathrm{mg}$ a day and only taking $\mathrm{I}_{5} \mathrm{mg}$, making a deficit during lactation of some $2 \mathrm{~g}$.

The mother's diet influences the milk so that random diversity is usually shared with the baby, while the overall constancy assists his survival.

\section{REFERENCES}

Antonov, A. N. (1947). 7. Pediat. 30, 250.

Belavady, B. \& Gopalan, C. (1950). Indian Y. med. Res. 47, 234.

Belavady, B., Venkatachalam, P. S. \& Gopalan, C. (1961). Indian F. med. Res. 49, 30r.

Bell, M. (1928). F. biol. Chem. 80, 239.

Cruickshank, J. D., Trimble, A. P. \& Brown, J. H. A. (1957). Archs Dis. Childh. 32, 279.

Dean, R. F. A. (1951). Spec. Rep. Ser. med. Res. Coun., Lond. no. 275, p.346.

Deb, A. K. \& Cama, H. R. (1962). Br. 7. Nutr. r6, 65.

Deem, H. E. (1931). Archs Dis. Childh. 6, 62.

Deodhar, A. D., Rajalakshmi, R. \& Ramakrishnan, C. V. (1964). Acta paediat., Stockh. 53, 42.

Descaine, M. E. (1871). Gaz. Méd. 26, 317.

Donnally, H. H. (x929). F. Allergy x, 78 .

27 (I) 6 
Dyggve, H. V., Dam, H. \& Sondergaard, E. (1956). Acta obstet. gynec. scand. 35, 440.

Fehily, L. (I944). Br. med. F. ii, 590 .

Fisch, R. O., Jenness, R., Doeden, D. \& Anderson, J. A. (1967). F. Pediat. 71, 176.

Gunther, M. \& Stanier, J. E. (I949). Lancet ii, 235.

Gunther, M. \& Stanier, J. E. (195 I). Spec. Rep. Ser. med. Res. Coun., Lond. no. 275, p.379.

Gunther, M., Hawkins, D. F. \& Whyley, G. A. (1965). F. Obstet. Gynaec. Br. Commonw. 72, 69.

Hawking, F. (1954). Br. med. F. i, 425.

Illingworth, R. S. \& Kilpatrick, B. ( (1953). Lancet $\mathbf{2 6}_{5}$, I 175 .

Insull, W. \& Ahrens, E. H. (I959). Biochem. 7. 72, 27.

Insull, W., Hirsch, J., James, T. \& Ahrens, E. H. (I959). F. clin. Invest. 38, 443 .

Jansen, A. A. J., Luyken, R., Malcolm, S. H. \& Willems, J. J. L. (I960). Trop. geogr. Med. 12, 138.

Karmarkar, M. G. \& Ramakrishnan, C. V. (r960). Acta paediat., Stockh. 49, 599.

Kon, S. K. \& Mawson, E. H. (1950). Spec. Rep. Ser. med. Res. Coun., Lond. no. 269.

Krámer, M., Szöke, K., Lindner, K. \& Tarján, R. (1965). Nutritio Dieta 7, 7 I.

Lavagne, J. \& Mathieu, S. (1943). Bull. Soc. Chim. biol. 25, i 12.

Luhby, A. L., Cooperman, J. M., Donnefeld, A. M., Herrero, J. M., Teller, D. N. \& Wenig, J. B. (1958). An. \%. Dis. Child. 98, 532.

Matoth, Y., Pinkas, A. \& Sroka, C. (1965). Am. F. clin. Nutr. 16, 356.

Peters, F. E. (1953). Br. F. Nutr. 7, 208.

Pokorný, J., Kohn, R. \& Pliška, V. (1963). Česlké Gastroent. 17, 371.

Pommerenke, W. 'T. \& Hahn, P. F. (1943). Proc. Soc. exp. Biol. Med. 52, 223.

Rao, R. R. \& Subrahmanyam, I. (1964). Indian \%. med. Res. 52, r 98.

Read, W. W. C., Lutz, P. G. \& Tashjian, A. (1965). Am. F. clin. Nutr. 17, r80.

Read, W. W. C. \& Sarrif, A. (1965). Am. F. clin. Nutr. 17, 177.

Ruzicic, U. S. (1936). Mschr. Kinderheilk. 67, 4I5.

Salmi, T. (1944). Acta paediat., Stockh. 32, I.

Smith, C. A. (1947). F. Pediat. 30, 229.

Soderhjelm, L. (r953). Acta Soc. Med. upsal. 58, 244.

Tanasiúchuk, O. F. (1965). Fiziol Zh. SSSR 5x, 867.

Tarján, R., Kramer, M., Szöke, K. \& Lindner, K. (1963). Nutritio Dieta 5, 12.

von Sydow, G. V. (1945). Acta paediat., Stockh. 32, 756 .

Young, T. (1 761). De Lacta, Edinburgh. 